\title{
Systems Engineering Plan and Project Record Configuration Management Plan for the Mixed Waste Disposal Initiative
}

\author{
W. E. Bryan \\ L. B. Oakley
}

Environmental Restoration Program

P.O. Box 2003

Oak Ridge, Tennessee 37831-7298

Date Issued-April 1993

\author{
Prepared by \\ Systems Engineering \\ Energy Systems Central Engineering Services \\ Oak Ridge, Tennessee 37831-6337 \\ Prepared for \\ U.S. Department of Energy
}

Office of Environmental Restoration and Waste Management under budget and reporting code EW 20

MARTIN MARIETTA ENERGY SYSTEMS, INC.

managing the

Oak Ridge K-25 Site

Oak Ridge Y-12 Plant

Oak Ridge National Laboratory under contract DE-AC05-84OR21400
Paducah Gaseous Diffusion Plant Portsmouth Gaseous Diffusion Plant under contract DE-AC05-76OR00001

for the

U.S. DEPARTMENT OF ENERGY 


\title{
Systems Engineering Plan and Project Record Configuration Management Plan for the Mixed Waste Disposal Initiative
}

\author{
ES/ER/TM-54
}

Approved by:

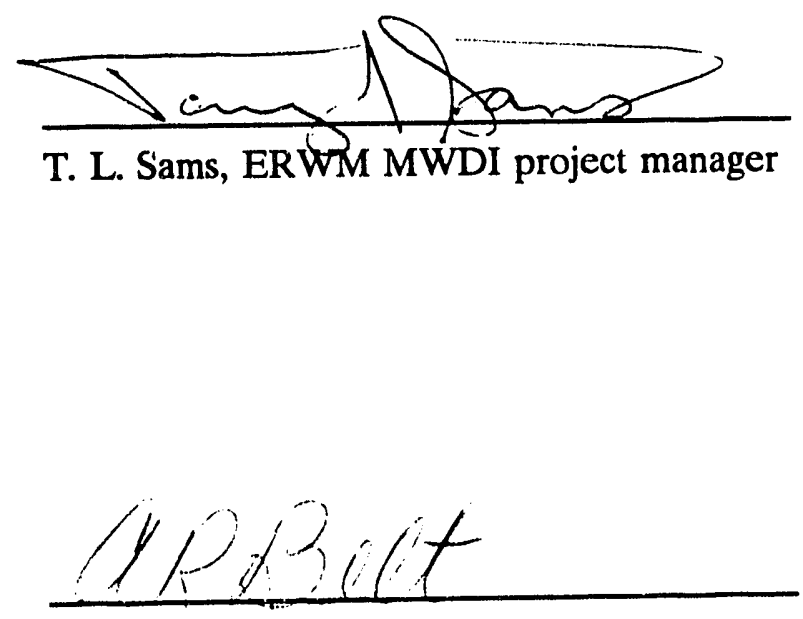

A. R. Belt, project engineer

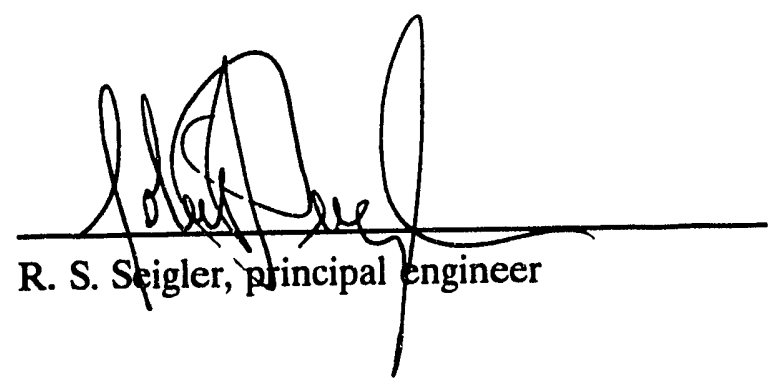

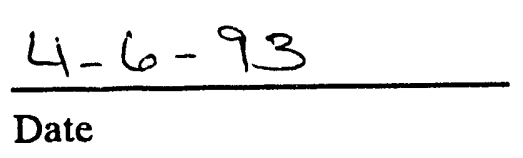

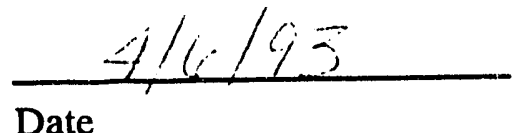

Date

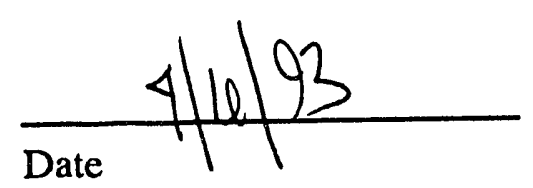


This document is designated System 2 by Engineering procedures pertaining to Design Document Change Control. 


\section{CONTENTS}

EXECUTIVE SUMMARY $\ldots \ldots \ldots \ldots \ldots \ldots \ldots \ldots \ldots \ldots \ldots \ldots \ldots \ldots \ldots \ldots$ iv

1. INTRODUCTION $\ldots \ldots \ldots \ldots \ldots \ldots \ldots \ldots \ldots \ldots \ldots \ldots \ldots \ldots \ldots \ldots \ldots \ldots \ldots$

2. SYSTEMS ENGINEERING ASSESSMENT $\ldots \ldots \ldots \ldots \ldots \ldots \ldots \ldots \ldots, 1$

3. CONFIGURATION MANAGEMENT PLAN $\ldots \ldots \ldots \ldots \ldots \ldots \ldots \ldots \ldots$

3.1 CONFIGURATION CONTROL BOARD $\ldots \ldots \ldots \ldots \ldots \ldots \ldots \ldots \ldots, 2$

3.2 ROLES AND RESPONSIBILITIES $\ldots \ldots \ldots \ldots \ldots \ldots \ldots \ldots \ldots \ldots, 2$

3.3 DESIGN-DOCUMENT CHANGE CONTROL $\ldots \ldots \ldots \ldots \ldots \ldots \ldots \ldots$

3.4 RECORDING AND REPORTING $\ldots \ldots \ldots \ldots \ldots \ldots \ldots \ldots \ldots \ldots, 4$

3.5 POST-PROJECT CONFIGURATION MANAGEMENT ............. 4 


\section{EXECUTIVE SUMMARY}

This document summarizes the systems engineering assessment that was performed for the Mixed Waste Disposal Initiative (MWDI) Project to determine what types of documentation are required for the success of the project. The report also identifies the documents that will make up the MDWI Project Record and describes the Configuration Management Plan for maintaining and controlling all MWDI Project documentation. The Configuration Management Plan describes the responsibilities and process for making changes to project documentation. 


\section{INTRODUCTION}

The systems approach will be integrated into the management, technical development, and verification of the Mixed Waste Disposal Initiative (MWDI) project. Pursuant to the guidelines for a Systems Engineering Management Plan (SEMP) presented in Department of Energy (DOE) Order 4700.1, Chapter III, this document presents a concise assessment of the systems effort identified by the project team for the MWDI. The management and conduct of the technical and engineering activities encompassed by this systems engineering process, typically presented in an SEMP, are to be integrated into the MWDI Project Management Plan. The documentation identified in this Systems Engineering Plan (SEP) will make up the MWDI Project Record.

This document will also serve as the Configuration Management Plan (CMP) for the MWDI Project Record. The CMP describes how the MWDI project team will manage changes to and deviations from the Project Record.

\section{SYSTEMS ENGINEERING ASSESSMENT}

The functional diagram in Fig. 1 identifies the key activities and interfaces required for completion of the MWDI. Identification of the elements included in MWDI systems integration is performed by applying the project activities and requirements checklist proposed by Martin Marietta Energy Systems, Inc., Systems Engineering personnel to each functional block in Fig. 1. Each item is evaluated as needed, depending upon its technical necessity or perceived value added to the project. Each assessment is made by the MWDI project team and is to be considered a starting point from which specific tasks are developed. Table 1 presents the resulting activities, identified by functional area, for a successful and auditable project. The project team's assignment of lead responsibility for each activity is based on the expertise and availability of project participants.

\section{CONFIGURATION MANAGEMENT PLAN}

The resulting documentation for the activities listed in Table 1 will make up the MWDI Project Record and shall be maintained and controlled in accordance with the Environmental Restoration Program record management procedures, all configuration management policies and procedures of DOE and Energy Systems, and MWDI project-specific requirements. If, during the course of this project, a conflict arises between this document and DOE orders or Energy Systems procedures, this document shall be revised as necessary to reflect resolution of the conflict. 
Because project-design documents are subject to engineering change-control procedures and because changes to design documents may result in changes to the project record, this document addresses change control for project-design documents.

The key Energy Systems procedures governing configuration management will be followed in completing this project.

\subsection{CONFIGURATION CONTROL BOARD}

A Configuration Control Board (CCB) will be established to review and approve proposed changes to the project record. The CCB for this project will consist of the following project team members:

MWDI Project Manager (PM) - Chairman

Project Engineer (PJ)

Principal Engineer (PE)

Systems Engineer (SE)

Temporary members who have the appropriate knowledge, will be appointed to the CCB to evaluate proposed changes that involve:

- Safety and Health issues

- Quality Assurance issues

- Transportation issues

- Environmental issues

- Waste Management issues

Representatives from the operating divisions, engineering disciplines, and other organizations will be consulted as needed to provide guidance on technical and/or operational issues.

\subsection{ROLES AND RESPONSIBILITIES}

The primary role of the $\mathrm{CCB}$ is to administer the project record of the MWDI. In performing this function, the $\mathrm{CCB}$ will be responsible for the following actions:

1. Providing traceability of all issues and dispositions by maintaining a log of all issues and changes referred to the board for action.

2. Reviewing and investigating, as required, all issues and changes referred to the board for technical feasibility and conformance to the project's mission requirements.

3. Approving or disapproving proposed resolutions to project-related issues and changes.

4. Ensuring that all impacts on the project baseline resulting from board actions are identified and documented.

5. Ensuring that the necessary changes to the project record and project baseline as a result of the resolution of an issue or project change are initiated upon approval and recorded. 
6. Reviewing every Project Change Order (PCO) associated with the project to determine its potential impacts on cost and/or schedule or technical requirements and ensuring that each PCO is processed in accordance with the Engineering procedure pertaining to Project Change Control.

It is the responsibility of all members of the MWDI project team to bring to the attention of the CCB any changes, or issues that may result in change. The CCB has the responsibility to determine if the proposed change is justified and if the impact of the change has been adequately scoped. If the magnitude of the change exceeds the authority of the $\mathrm{CCB}$, then the proposed change must be elevated to the appropriate change control level at DOE.

The CCB will meet either formally or informally, as required, to carry out these responsibilities. CCB meetings will be called by the chairperson to provide appropriate and timely evaluation of the proposed change(s). Minutes of the $\mathrm{CCB}$ meetings will document all $\mathrm{CCB}$ actions and contain the approved changes to the current project record documents. Concurrence of at least three members of the $\mathrm{CCB}$, including the project manager and the project engineer, is required for approval of a change. In the event that disputes arise that cannot be resolved among the members of the $C C B$, the issue will be referred to the ERWM MWDI project manager.

\subsection{DESIGN-DOCUMENT CHANGE CONTROL}

Project documents that are deemed "design documents" are subject to the Engineering procedure pertaining to Design Document Change Control, which establishes the Change Control System for review and approval of project design documents. Documents designated as "System 1" include project design requirements that are prescribed by DOE; changes to these documents must be reviewed and approved by the CCB and DOE. Documents designated as "System 2" include requirements from several Energy Systems organizations; changes to these documents must be reviewed and approved by the CCB and representatives from the appropriate organizations. Documents designated as "System 3" include requirements generated within the project team; changes to these documents are reviewed and approved by the project engineer and the principal engineer with timely input from appropriate members of the project team. All design documents will have a Change Control System designation when they are issued upon approval.

\subsection{RECORDING AND REPORTING}

Each change approved by the CCB, as well as the final CCB log, shall be treated as a Project Record copy in accordance with ER Program record management procedures.

The approved PCOs will be transmitted to the appropriate project team members and to appropriate levels of Energy Systems and DOE management. 


\subsection{POST-PROJECT CONFIGURATION MANAGEMENT}

The project's transition plans will ensure a smooth transition to the operation divisions at the project's completion. The operating divisions will be responsible for identifying configured items and establishing a baseline and Configuration Management Plan for the operations. The systems requirements document, as-built design documents, specifications and drawings, safety analysis and assessments, vendor data, maintenance procedures, spare parts specifications, operating procedures, and training documents will form the basis of the operations baseline documentation. 


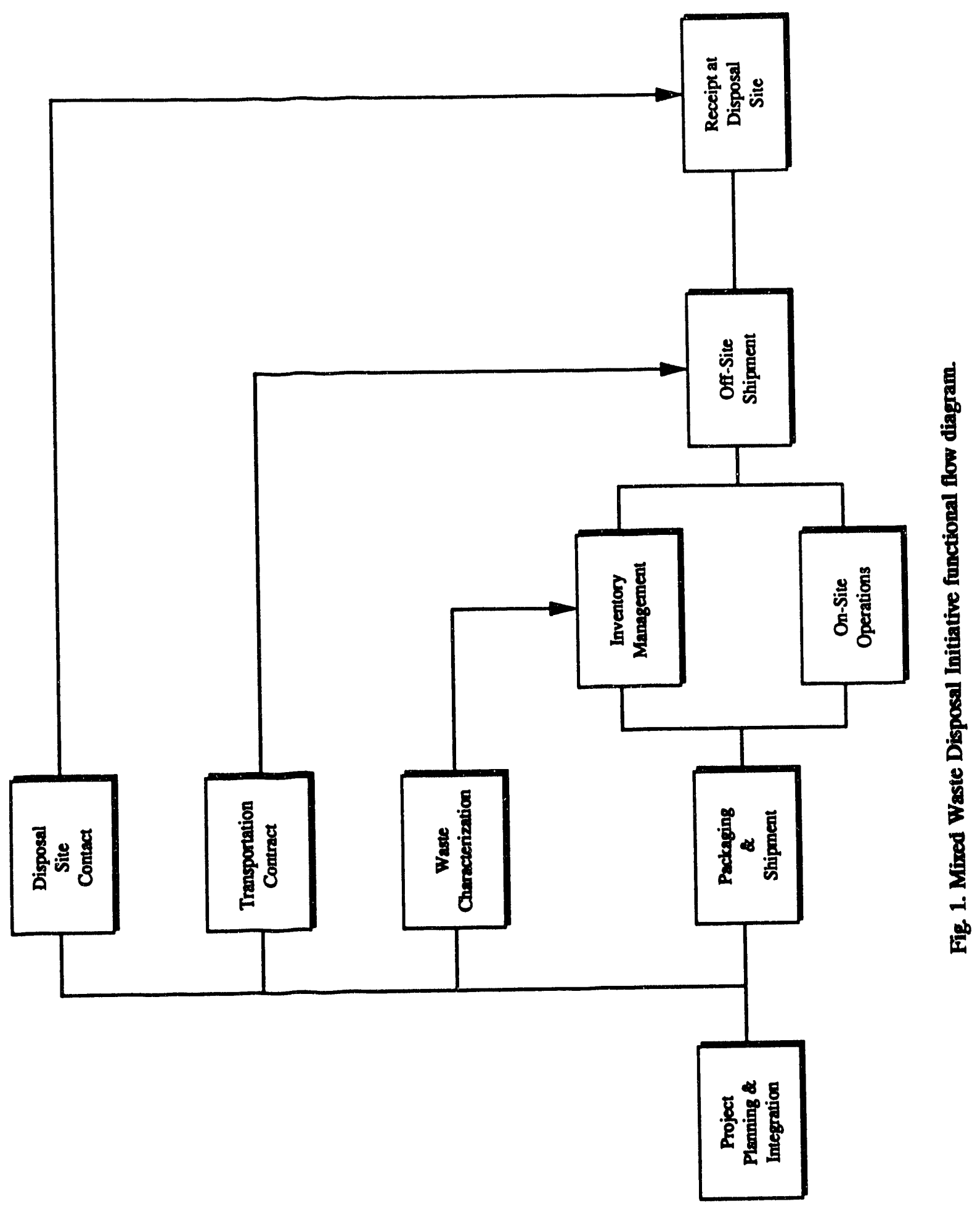


Table 1. Systems Integration for Mired Waste Disposal Initiative

$\frac{\text { Activity }}{\text { Project planning and integration }}$

Systems Engineering Plan/Configuration Management Plan

System Requirements Document

Feasibility Study

Current Year Work Plan

Action Plan for Off-Site Disposal of K-25 Pond Waste

Project Management Implementation Plan

Project Quality Assurance Plan

Operational Readiness Review :Jan

NEPA Documentation

RCRA Permitting

Order 5820.2A Exemption

Nuclear Material Transaction Report

Evaluation of Available Mixed Waste Disposal Sites

\section{Packaging and shipment}

Shipping container specification and independent design review

Configuration Management Plan (Waste Management Operations)

\section{On-site operations}

Transportation, handling, and packaging work instructions (job-specific)

Secondary Waste Management Plan

Safety assessment

On-site risk assessment

Site health and safety plan

Spill Prevention Control and Countermeasures Plan (Best Management Practices Plan)

\section{Inventory management}

Waste certification plan

IMIS downloading instructions

Waste manifests
Lead responsibility

Systems engineer

ERWM

Principle engineer

Project manager

Project manager

Systems engineer

K-25 Waste Management Dept.

ERWM

Project manager

K-25 Environmental Management Dept.

Project manager

Project manager

Project manager

Principle engineer

K-25 Waste Management Dept.

Principle engineer

To be determined

System safety engineer

Systems engineer

Systems engineer

K-25 Waste Management Dept.

Project manager

K-25 Waste Management Dept. K-25 Waste Management Dept. 
Table 1. (continued)

\begin{tabular}{|c|c|}
\hline Activity & Lead responsibility \\
\hline \multicolumn{2}{|c|}{ Off-site shipment } \\
\hline Transportation risk assessment/analysis & Project manager \\
\hline Safety assessment & Project manager \\
\hline Security plan & Project manager \\
\hline Contingency plan and notification procedures & Project manager \\
\hline \multicolumn{2}{|c|}{ Waste characterization } \\
\hline Statistical sampling plan & K-25 Statistical sampling \\
\hline Analytical report & K-25 Statistical sampling \\
\hline Characterization summary report & Project manager \\
\hline \multicolumn{2}{|c|}{$\begin{array}{c}\text { Thansportation contract (DOE to countersign) } \\
\text { K-25 Traffic Department }\end{array}$} \\
\hline Life-cycle cost analysis for locomotive & Systems engineer \\
\hline Locomotive lease & Project manager \\
\hline \multicolumn{2}{|c|}{ Dispasal site contract (DOE-OR) } \\
\hline Waste acceptance criteria & Disposal site \\
\hline
\end{tabular}


ES/ER/TM-54

\section{DISTRIBUTION}

1. J. K. Bailey

2. D. T. Bell

3. A. R. Belt

4. M. E. Bennett

5. J. E. Brewer

6. W. E. Bryan

7. J. M. Cash

8. L. D. Charles

9. H. M. Clancy

10. M. F. P. DeLozier

11. D. M. Dutton

12. C. D. Goins

13. J. A. Graudons

14. J. T. Grumski

15. P. J. Halsey

16. F. K. Heacker, Jr.

17. M. J. Landguth

18. A. C. Lay

19. B. Lester

20. L. W. Little

21-23. D. M. Matteo
24. H. B. Nennstiel

25. L. B. Oakley

26-27. P. T. Owen

28. S. M. Parsons

29-30. E. J. Powell

31. E. Raines, Jr.

32. J. R. Rivers

33. G. E. Rymer

34-38. T. L. Sams

39. R. S. Seigler

40. M. J. Shelton

41. J. G. Snipes

42. D. F. Stancell

43. R. K. White

44. J. S. Colley

45. D. R. Watkins

46. Central Research Library

47-51. ER Document Management Center-RC

52. ORNL Laboratory Records

53. D. M. Carden, DOE Oak Ridge Field Office, P.O. Box 2001, Oak Ridge, TN 37831-8541

54. D. W. Swindle, Radian Corporation, 120 South Jefferson Circle, Oak Ridge, TN 37830

55-56. R. L. Nace, Branch Chief, Nonenrichment Facilities, Oak Ridge Program Division, Office of Eastern Area Programs, Office of Environmental Restoration, EM-423, Trevion 2, U.S. Department of Energy, Washington, DC 20585

57-61. E. J. Powell, DOE Oak Ridge Field Office, P.O. Box 2001, Oak Ridge, TN 37831-8541

62-63. H. M. Thron, Chief, Enrichment Facilities, Oak Ridge Program Division, Office of Eastern Area Programs, Office of Environmental Restoration, EM-423, Trevion 2, U.S. Department of Energy, Washington, DC 20585

64-65. Office of Scientific and Technical Information, P.O. Box 62, Oak Ridge, TN 37831 

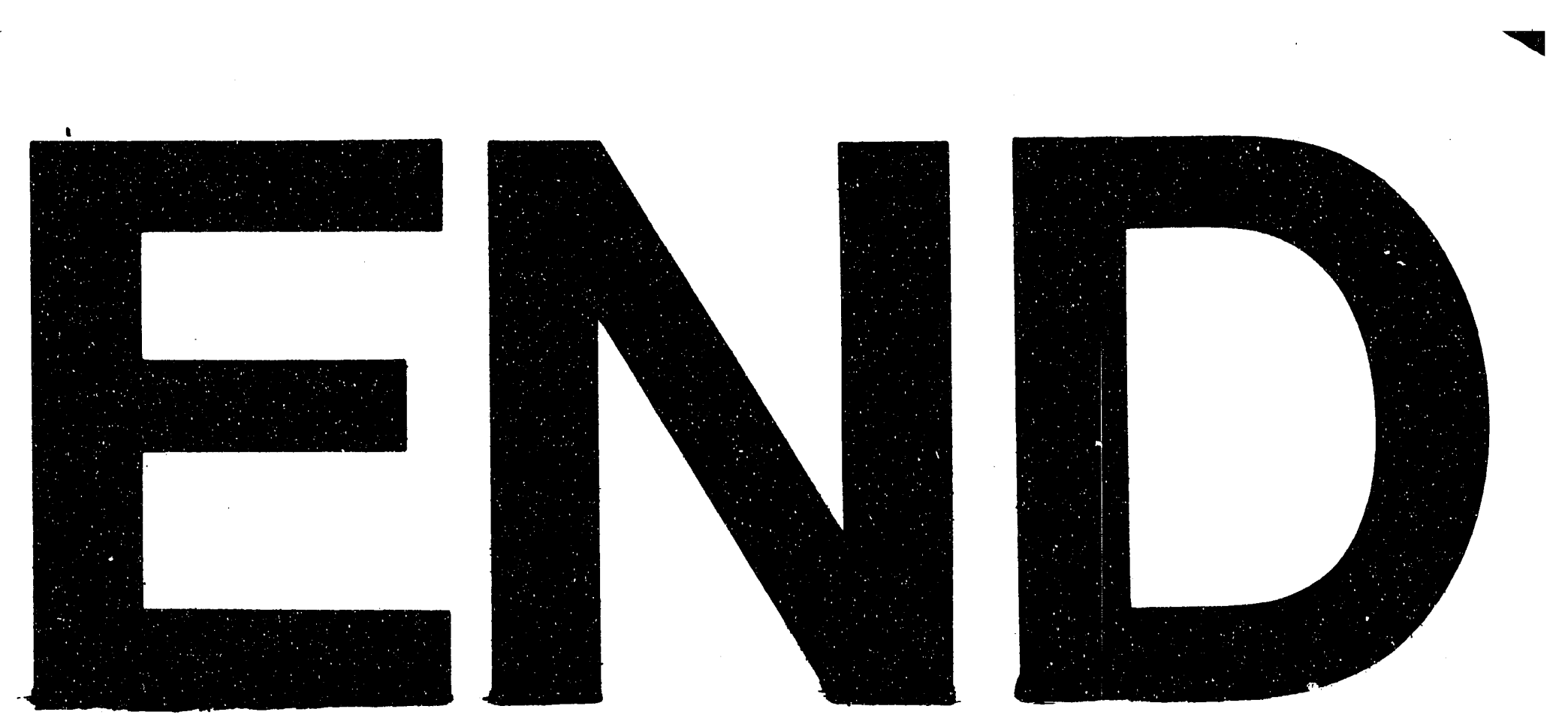

$x$

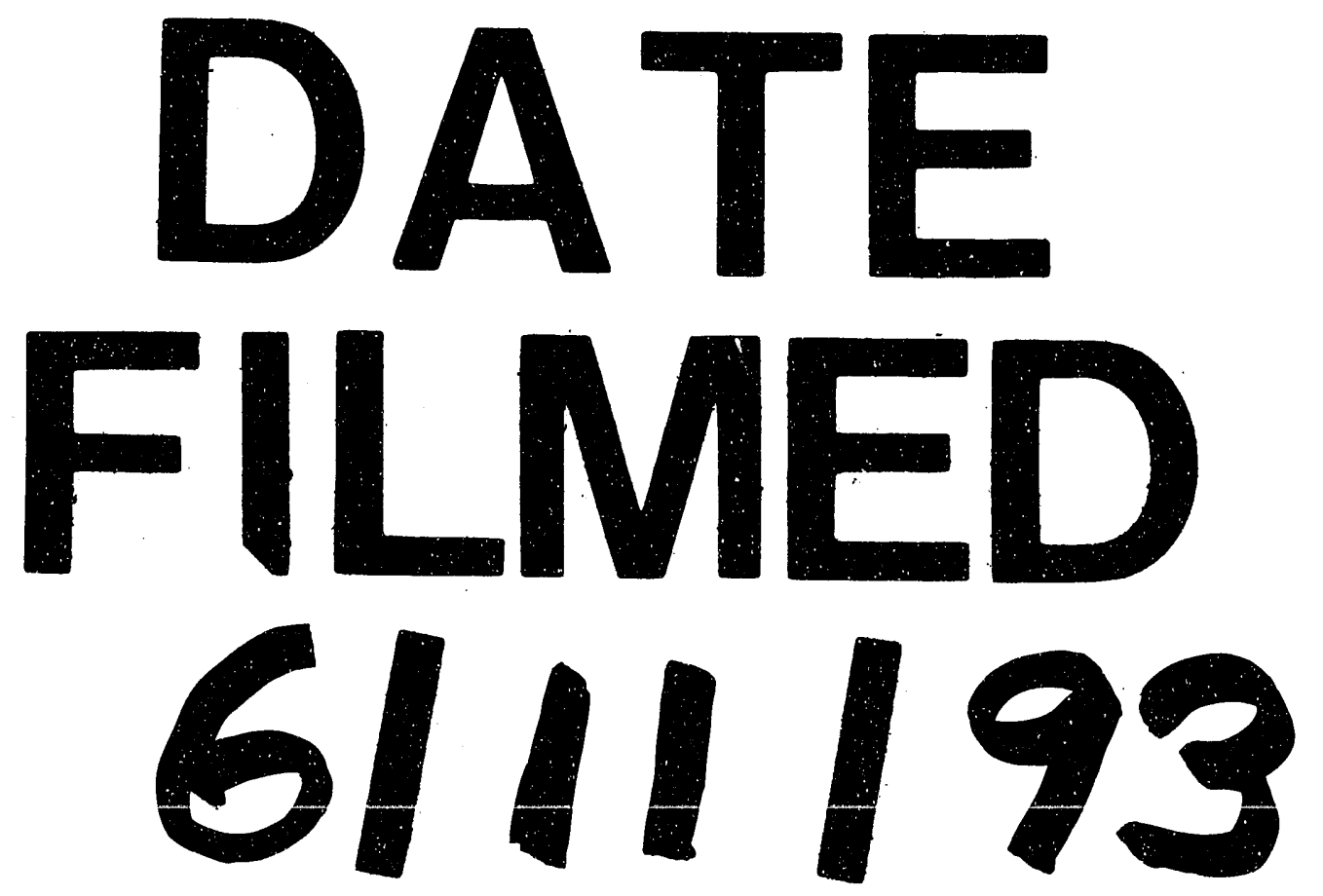


